(2) Open Access Full Text Article

REVIEW

\title{
Dietary gluten and the development of celiac disease and type I diabetes
}

This article was published in the following Dove Press journal:

Nutrition and Dietary Supplements

21 April 2016

Number of times this article has been viewed

\section{Carolina Ciacci \\ Fabiana Zingone \\ Department of Medicine and Surgery, Celiac Center, University of Salerno, Fisciano, Italy}

\begin{abstract}
The objective of this study was to perform a review of the present knowledge on the epidemiology and pathogenesis of the association between celiac disease (CD) and type 1 diabetes mellitus (T1DM). Results from this review show that the estimated prevalence rate of CD in T1DM ranges from $4 \%$ to $11.5 \%$, which seems higher in children than in adults, while there is no sex predominance in the prevalence of CD in T1DM. On the basis of the previous literature, screening for $\mathrm{CD}$ should be considered at diabetes diagnosis in all subjects and again within 2 and 5 years after diagnosis, even in the absence of symptoms. The anti-islet antibodies detection test, instead, is not recommended in CD, just as in the general population, except for CD patients having a relative with T1DM. Both genes and environmental factors seem to play a role in this association. HLADQ2 has been found to be the most frequent allele in the patients with both CD and T1DM, while gluten may be considered the trigger that induces the production of autoantibodies and the development, in genetically predisposed individuals, of both diseases.
\end{abstract}

Keywords: diabetes, celiac disease, genetics, environmental, epidemiological

\section{Introduction}

Celiac disease (CD) and type 1 diabetes mellitus (T1DM) are immune-mediated diseases that occur in genetically predisposed individuals. The causative agent of CD, "the gluten" is a protein contained in some cereals like wheat, which, once ingested and partially digested, induces an immunological response in the intestinal mucosa. On the contrary, it is still unknown what specific agent causes the destruction of the $\beta$-cells of the pancreas. Historically, it was believed that both diseases affected only children, but nowadays, it is known that CD can be diagnosed at any age, as can T1DM. In fact, although the latter remains the most common form of diabetes affecting children and adolescents, it can also be diagnosed during adulthood. CD may show a wide range of symptoms, or even be asymptomatic, and diagnosed only during screening programs. Similarly, T1DM can be diagnosed with the classic symptoms of new-onset chronic polydipsia, polyuria, and weight loss with hyperglycemia and ketonemia (or ketonuria), but it can also be discovered incidentally. ${ }^{1-4}$

We performed this review with the aim of discussing the present knowledge on the epidemiology and pathogenesis of the association between CD and T1DM. We searched PubMed for English-language articles published between 1900 and August 2015 for all the terms related to CD and T1DM. This search resulted in 1,319 papers, of which 293 were related reviews. Papers dealing with epidemiology and pathogenesis 
of the association of CD and T1DM were extracted, after which the most significant ones were used for this review.

\section{Epidemiology}

The first reported case of T1DM and CD in the same patient was described by Payne ${ }^{5}$ in 1954 , with the association becoming evident in the early 1960s. Since then, some studies have confirmed the association, and nowadays, the estimated prevalence rate of CD in T1DM ranges from 4\% to $11.5 \%{ }^{6-15}$

A recent pooled analysis, taking into account 27 studies with a total of 26,605 patients with T1DM, found a prevalence of biopsy-confirmed CD of $6.0 \%$ (95\% confidence interval $[\mathrm{CI}]=5.0 \%-6.9 \%)$. The prevalence was highest among children $(6.2 \%)$ and lowest among adults $(2.7 \%) .{ }^{16}$ The heterogeneity of the prevalence of the association between CD and T1DM might be explained mostly by the age at screening, but can also be associated with the screening strategy and the tests used to diagnose CD. However, the prevalence of both diseases has increased over time; thus, the variability can also be related to the time the study was performed. ${ }^{17-20}$

Like other autoimmune diseases, ${ }^{21} \mathrm{CD}$ is more frequent in females than in males, with a ratio of around $2.5: 1 .^{22}$ Conversely, T1DM is the only major organ-specific autoimmune disorder that does not show a strong female bias, while it is predominant in males, in particular, in countries with a high incidence. ${ }^{23}$ The previous literature reported contradictory results between the sexes for the prevalence of CD in T1DM. The prevalence was higher in females in some studies, ${ }^{13,24}$ higher in males in others, ${ }^{25,26}$ and yet other studies reported no difference. ${ }^{27,28}$ However, a meta-analysis published in 2014 described no sex predominance in the prevalence of CD in T1DM. ${ }^{16}$

A recent review ${ }^{29}$ analyzed nine longitudinal cohort studies dealing with CD screening in T1DM children. The nine studies included altogether 11,157 children and adolescents with T1DM, of whom 587 had biopsy-reported CD (median follow-up 10 years). The pooled prevalence of CD was $5.1 \%$. Only 41 cases (7\%) were diagnosed with CD onset before T1DM, while CD was diagnosed in the first year from T1DM onset in 218 of 546 (40\%) subjects. Thus, the important information derived from the Pham-Short et al ${ }^{29}$ review is that, since $55 \%$ of cases were diagnosed within 2 years and $79 \%$ within 5 years from diabetes onset, screening for CD should be considered at diabetes diagnosis and again within 2 and 5 years after diagnosis. This datum is also confirmed by Larsson et al, ${ }^{25}$ who suggested a screening for CD at the onset of T1DM, and annually for a minimum of at least 2 years.
The major limitation of the current data, however, is that almost all the screening studies deal with cohorts of T1DM children, and so the derived figures cannot be extrapolated for adults with T1DM. The reason to emphasize the notion of screening for CD in T1DM is that CD remains more often undiagnosed because of the low prevalence of gastrointestinal symptoms. ${ }^{30}$ Apart from gastrointestinal symptoms, some studies have reported a poor control of glycemia level, which improves after initiation of the gluten-free diet (GFD). ${ }^{31}$ However, based on the examined epidemiological studies on the prevalence of CD in T1DM, patients with T1DM should be routinely screened for $\mathrm{CD}$.

No guideline indicates a specific timing for the screening because there is no longitudinal follow-up study on the onset of CD beyond 5 years of T1DM duration, despite the cast-iron certainty of the increased prevalence of CD in T1DM.

On the contrary, Kabbani et $\mathrm{al}^{32}$ showed that $\mathrm{CD}$ patients on a GFD have a low risk of noninsulin-dependent diabetes mellitus, suggesting that the gluten contained in the diet may have a central role in causing the association of both diseases. No possibility exists that the onset of T1DM in CD could be less frequently detected, as it rarely continues nondiagnosed (as CD might in T1DM patients). In fact, the body's inability to produce insulin as a consequence of the autoimmune destruction of the $\beta$-cells in the pancreas causes some symptoms leading to a prompt T1DM diagnosis. T1DM diagnosis in patients with CD most often occurs in childhood, but it may also appear in adults in their late 30 s and early 40 s. However, there are no guidelines, and, at the moment, the anti-islet antibodies detection test is not recommended in CD, just as in the general population. ${ }^{33,34}$ The only exception where the anti-islet antibody detection test is recommended is for CD patients having relatives with T1DM, because they are at risk. ${ }^{35}$

The reason for the diminished prevalence of T1DM after $\mathrm{CD}$ diagnosis is unclear, but it can be speculated that although the triggers for CD and T1DM are different, GFD and recovery of the intestinal mucosal barrier may play a role in inducing a sort of protection. Regarding this, recently it has been reported that the microbiota composition in the early gut is different between nonobese diabetic (NOD) mice that later in life become diabetic and non-diabetic. In particular, some Bacteroidetes are related to diabetes protection, whereas members of Firmicutes promote pathogenesis. ${ }^{36}$

The possibility of spontaneous normalization has been reported for elevated titer serum concentration of CD-related antibodies in $28 \%$ of 446 children with T1DM who chose not to follow a GFD. ${ }^{37}$ Low titers of antitransglutaminase IgA 
(TTG) antibodies (below eightfold the normal value) and anti-endomysial (EMA) negativity were the best predictors of spontaneous seroconversion. Moreover, no major events have been reported in EMAs and/or TTG-positive patients who, at diabetes diagnosis, chose not to follow the GFD, although they showed some nutritional deficiency at follow-up. ${ }^{38}$

\section{Pathogenesis Genetics}

Genetics plays a role in both diseases, and overlap of genes may account for their co-occurrence. ${ }^{39}$ Kumar et $\mathrm{al}^{40}$ have recently summarized the results of several genetic studies that utilized the genome-wide association study technique to show genes and pathways involved in both the CD and T1DM phenotypes. In fact, the majority of $\mathrm{CD}$ patients express $H L A-D R 3 / D Q 2$ haplotype, and the same haplotype is present in $55 \%$ of those with T1DM and about $25 \%$ of the general population. ${ }^{41}$ Homozygosis for $H L A D Q 2$ confers the highest risk to develop $\mathrm{CD}$, while homozygosis for $H L A D Q 8$ confers the highest risk for T1DM. ${ }^{42} H L A D Q 2$, however, has been found to be the most frequent allele in the patients with both CD and T1DM. ${ }^{43-45}$ The HLADQ 8 transdimer recognizes gluten and binds efficiently both gliadin peptides and also peptides derived from glutamic acid decarboxylase and islet cells antibody (IA-2). ${ }^{46}$ As for CD, HLA genes are not the only genes contributing to T1DM. ${ }^{47}$ A recent study reported that $K I R$ genes play a role in the pathogenesis of the association between CD and T1DM. ${ }^{48}$ Also, a recent genome-wide linkage and association analysis has shown the presence in $\mathrm{CD}$ of two out of three loci already known to be involved in regulating plasma glucose levels in T1DM. ${ }^{49} \mathrm{CD}$ and T1DM also share the IL-2/21 susceptibility locus, which is known to be associated with multiple autoimmune diseases. ${ }^{50-52}$ In particular, all these studies highlight the role of IL-21, which is known to induce interferon- $\gamma$ production and regulate proliferation and survival of natural killer and CD8 T-cells in several autoimmune diseases. Genetics may also be involved in the clinical presentation of CD in T1DM. In fact, about $90 \%$ of T1DM patients at the time of diagnosis of CD have little or no gastrointestinal symptoms. ${ }^{53}$ In the majority of cases, the CD diagnosis follows that of T1DM as a consequence of case-finding at diagnosis or follow-up; thus, CD is found at an early stage in patients with T1DM. On the contrary, there is a paucity of data on the onset of T1DM in patients with treated CD. ${ }^{54}$ Genetically-induced lipid metabolism impairment often seen in CD patients with T1DM seems to be a consequence of T1DM and not related to the association. In fact, Tarnok et al ${ }^{55}$ found low levels of n-3 long-chain poly- unsaturated fatty acids in children with newly-diagnosed CD along with preexisting T1DM. The study suggests that CD on its own does not necessarily lead to impairment of essential fatty acid metabolism in plasma and supports the concept that T1DM has a significant impact on plasma fatty acid composition in children. Finally, an Italian study reported a 5.3\% prevalence of immunoglobulin A deficiency in T1DM; ${ }^{56}$ this was higher than that reported in $\mathrm{CD} .{ }^{57}$

\section{Environment}

It is believed that environmental factors, including nutrition, trigger the autoimmune process that precedes the development of T1DM. In children younger than 5 years of age, the early introduction of gluten has been involved in the etiology of T1DM with conflicting results. ${ }^{58,59}$ Previous studies showed an increased risk of islet autoimmunity when food containing gluten ${ }^{60}$ or any cereals ${ }^{61}$ were introduced during the first 3 months of life in children at high risk for T1DM.

A substantially lower diabetes incidence was initially observed in NOD mice never exposed to a diet containing gluten (15\%), compared to mice on the standard diet (64\%). ${ }^{62}$ However, in a successive study, the same authors surprisingly found that a gluten-enriched diet prevented diabetes in mice as efficiently as the GFD did. ${ }^{63}$ The authors postulate two different mechanisms explaining the dually ambiguous response of NOD mice to gluten: activation of the immunity in the gut mucosa in the presence of low gluten doses and immunotolerance for very high doses.

Gluten might have a direct effect on pancreatic $\beta$-cells since it modulates the immune system and affects the pancreatic $\beta$-cells. ${ }^{64}$ The 33 -mer gliadin peptide (an immunogenic active peptide, made of residues 57-89 of $\alpha 2$-gliadin) and gluten (digested with digestive enzymes) increased in vitro, the long-term (24 hours), but not the short-term (30 minutes), insulin secretion via the closure of the ATP-sensitive $\mathrm{K}$-channels. In vivo, NOD mice, injected with gliadin digest, were heavier as adults, probably reflecting the higher insulin secretion from the islets. ${ }^{65} \beta$-cell stress contributes to diabetes onset by increasing antigen expression, whereas prophylactic insulin treatment induces a reduction of diabetes incidence in diabetes-prone animals. ${ }^{66}$ Some studies highlight the role of microbiota in degrading the toxic gluten proteins and/or regulating immunotolerance to gluten. ${ }^{67-69}$

It has also been shown that bacteria present in the gut may hydrolyze dietary gluten. ${ }^{70}$ Thus, it can be speculated that a defective/altered microbiome may cause loss of immunotolerance and the onset, in genetically susceptible individuals, of both CD and T1DM. 
Finally, viral infections have been suggested to play a role in triggering many autoimmune conditions, including CD and T1DM. The evidence is both epidemiologic and genetic. The Toll-like receptors (TLR) 7 and 8 genes, encoding for the innate receptors for single-stranded viral RNA and related to the antiviral responses, ${ }^{71}$ have been found to be associated with CD. ${ }^{72}$ Similarly, the TLR3 and TLR4 genes, which play an important role in the innate immune response triggered by viral infection, are responsible for the development of both T1DM and CD. ${ }^{42,73,74}$

\section{Conclusion}

In conclusion, in the absence of gastrointestinal symptoms, and/or growth failure and/or iron deficiency, CD blood tests should be performed at T1DM diagnosis and routinely repeated within 5 years from diagnosis, even in the absence of gastrointestinal symptoms. Conversely, the anti-islet antibody detection test is recommended for a $\mathrm{CD}$ patient having a relative with T1DM, as he/she is considered to be at risk. HLADQ2 has been found to be the most frequent allele in patients with both CD and T1DM, but several others genes seem to be related to both diseases. Gluten, in the case of the association of CD and T1DM, may be considered the trigger that induces the production of autoantibodies and the development, in genetically predisposed individuals, of both diseases.

\section{Disclosure}

The authors report no conflicts of interest in this work.

\section{References}

1. Ludvigsson JF, Leffler DA, Bai JC, et al. The Oslo definitions for coeliac disease and related terms. Gut. 2013;62(1):43-52.

2. Ludvigsson JF, Bai JC, Biagi F, et al. Diagnosis and management of adult coeliac disease: guidelines from the British Society of Gastroenterology. Gut. 2014;63(8):1210-1228.

3. Forouhi NG, Wareham NJ. Epidemiology of diabetes. Medicine (Abingdon). 2014;42(12):698-702.

4. Atkinson MA, Eisenbarth GS, Michels AW. Type 1 diabetes. Lancet. 2014;383(9911):69-82.

5. Payne WW. Coeliac disease and diabetes mellitus in the same patient. Great Ormond St J. 1954;8:118-122.

6. Aktay AN, Lee PC, Kumar V, Parton E, Wyatt DT, Werlin SL. The prevalence and clinical characteristics of celiac disease in juvenile diabetes in Wisconsin. J Pediatr Gastroenterol Nutr. 2001;33(4):462-465.

7. Cronin CC, Feighery A, Ferriss JB, Liddy C, Shanahan F, Feighery C. High prevalence of celiac disease among patients with insulin-dependent (type I) diabetes mellitus. Am J Gastroenterol. 1997;92(12):2210-2212.

8. Goh VL, Werlin SL. Discovery of gluten as the injurious component in celiac disease. Nutr Clin Pract. 2011;26(2):160-162.

9. Karavanaki K, Kakleas K, Paschali E, et al. Screening for associated autoimmunity in children and adolescents with type 1 diabetes mellitus (T1DM). Horm Res. 2009;71(4):201-206.

10. Sanchez-Albisua I, Wolf J, Neu A, Geiger H, Wascher I, Stern M. Coeliac disease in children with type 1 diabetes mellitus: the effect of the gluten-free diet. Diabet Med. 2005;22(8):1079-1082.
11. Rosario N, Landgraf LF. Serum prevalence of celiac disease in children and adolescents with type 1 diabetes mellitus. J Pediatr. 2006;82(5):400-401; author reply 401.

12. Bhadada SK, Kochhar R, Bhansali A, et al. Prevalence and clinical profile of celiac disease in type 1 diabetes mellitus in north India. J Gastroenterol Hepatol. 2011;26(2):378-381.

13. Poulain C, Johanet C, Delcroix C, Levy-Marchal C, Tubiana-Rufi N. Prevalence and clinical features of celiac disease in 950 children with type 1 diabetes in France. Diabetes Metab. 2007;33(6):453-458.

14. Ludvigsson JF, Ludvigsson J, Ekbom A, Montgomery SM. Celiac disease and risk of subsequent type 1 diabetes: a general population cohort study of children and adolescents. Diabetes Care. 2006;29(11):2483-2488.

15. Collin P, Salmi J, Hallstrom O, et al. High frequency of coeliac disease in adult patients with type-I diabetes. Scand J Gastroenterol. 1989;24(1):81-84.

16. Elfstrom P, Sundstrom J, Ludvigsson JF. Systematic review with metaanalysis: associations between coeliac disease and type 1 diabetes. Aliment Pharmacol Ther. 2014;40(10):1123-1132.

17. Kang J, Kang A, Green A, Gwee K, Ho K. Systematic review: worldwide variation in the frequency of coeliac disease and changes over time. Aliment Pharmacol Ther. 2013;38(3):226-245.

18. Patterson CC, Dahlquist GG, Gyurus E, Green A, Soltesz G, Group ES. Incidence trends for childhood type 1 diabetes in Europe during 1989-2003 and predicted new cases 2005-2020: a multicentre prospective registration study. Lancet. 2009;373(9680):2027-2033.

19. Dabelea D, Mayer-Davis EJ, Saydah S, et al. Prevalence of type 1 and type 2 diabetes among children and adolescents from 2001 to 2009. JAMA. 2014;311(17):1778-1786.

20. Salardi S, Volta U, Zucchini S, et al. Prevalence of celiac disease in children with type 1 diabetes mellitus increased in the mid-1990s: an 18-year longitudinal study based on anti-endomysial antibodies. $J$ Pediatr Gastroenterol Nutr. 2008;46(5):612-614.

21. Quintero OL, Amador-Patarroyo MJ, Montoya-Ortiz G, Rojas-Villarraga A, Anaya J-M. Autoimmune disease and gender: plausible mechanisms for the female predominance of autoimmunity. J Autoimmun. 2012;38(2):J109-J119.

22. Ciacci C, Cirillo M, Sollazzo R, Savino G, Sabbatini F, Mazzacca G. Gender and clinical presentation in adult celiac disease. Scand J Gastroenterol. 1995;30(11):1077-1081.

23. Gale EA, Gillespie KM. Diabetes and gender. Diabetologia. 2001;44(1):3-15.

24. Cerutti F, Bruno G, Chiarelli F, et al. Younger age at onset and sex predict celiac disease in children and adolescents with type 1 diabetes: an Italian multicenter study. Diabetes Care. 2004;27(6):1294-1298.

25. Larsson K, Carlsson A, Cederwall E, et al. Annual screening detects celiac disease in children with type 1 diabetes. Pediatr Diabetes. 2008;9(4 Pt 2):354-359.

26. Crone J, Rami B, Huber WD, Granditsch G, Schober E. Prevalence of celiac disease and follow-up of EMA in children and adolescents with type 1 diabetes mellitus. J Pediatr Gastroenterol Nutr. 2003; 37(1):67-71.

27. Pham-Short A, Donaghue KC, Ambler G, Chan AK, Craig ME. Coeliac disease in Type 1 diabetes from 1990 to 2009: higher incidence in young children after longer diabetes duration. Diabet Med. 2012;29(9):e286-e289.

28. Glastras SJ, Craig ME, Verge CF, Chan AK, Cusumano JM, Donaghue KC. The role of autoimmunity at diagnosis of type 1 diabetes in the development of thyroid and celiac disease and microvascular complications. Diabetes Care. 2005;28(9):2170-2175.

29. Pham-Short A, Donaghue KC, Ambler G, Phelan H, Twigg S, Craig ME. Screening for celiac disease in type 1 diabetes: a systematic review. Pediatrics. 2015;136(1):e170-e176.

30. Holmes GK. Screening for coeliac disease in type 1 diabetes. Arch Dis Child. 2002;87(6):495-498.

31. Iafusco D, Rea F, Chiarelli F, Mohn A, Prisco F. Effect of gluten-free diet on the metabolic control of type 1 diabetes in patients with diabetes and celiac disease. Diabetes Care. 2000;23(5):712-713. 
32. Kabbani TA, Kelly CP, Betensky RA, et al. Patients with celiac disease have a lower prevalence of non-insulin-dependent diabetes mellitus and metabolic syndrome. Gastroenterology. 2013;144(5):912-917. e911.

33. American Diabetes Association. Diagnosis and classification of diabetes mellitus. Diabetes Care. 2010;33(Suppl 1):S62-S69.

34. Hansson T, Dahlbom I, Tuvemo T, Frisk G. Silent coeliac disease is over-represented in children with type 1 diabetes and their siblings. Acta Paediatr. 2015;104(2):185-191.

35. Gillett MJ. International Expert Committee report on the role of the A1c assay in the diagnosis of diabetes. Diabetes Care. 2009;32(7): 1327-1334.

36. Krych L, Nielsen DS, Hansen AK, Hansen CH. Gut microbial markers are associated with diabetes onset, regulatory imbalance, and IFNgamma level in NOD mice. Gut Microbes. 2015;6(2):101-109.

37. Castellaneta S, Piccinno E, Oliva M, et al. High rate of spontaneous normalization of celiac serology in a cohort of 446 children with type 1 diabetes: a prospective study. Diabetes Care. 2015;38(5):760-766.

38. Simmons JH, Klingensmith GJ, McFann K, et al. Celiac autoimmunity in children with type 1 diabetes: a two-year follow-up. J Pediatr. 2011;158(2):276-281. e271.

39. Smyth DJ, Plagnol V, Walker NM, et al. Shared and distinct genetic variants in type 1 diabetes and celiac disease. $N$ Engl J Med. 2008; 359(26):2767-2777.

40. Kumar V, Wijmenga C, Withoff S. From genome-wide association studies to disease mechanisms: celiac disease as a model for autoimmune diseases. Semin Immunopathol. 2012;34(4):567-580.

41. Rewers M, Eisenbarth GS. Autoimmunity: celiac disease in T1DM-the need to look long term. Nat Rev Endocrinol. 2012;8(1):7-8.

42. Dezsofi A, Szebeni B, Hermann CS, et al. Frequencies of genetic polymorphisms of TLR4 and CD14 and of HLA-DQ genotypes in children with celiac disease, type 1 diabetes mellitus, or both. J Pediatr Gastroenterol Nutr. 2008;47(3):283-287.

43. Hermann R, Turpeinen H, Laine AP, et al. HLA DR-DQ-encoded genetic determinants of childhood-onset type 1 diabetes in Finland: an analysis of 622 nuclear families. Tissue Antigens. 2003;62(2):162-169.

44. Larizza D, Calcaterra V, Klersy C, et al. Common immunogenetic profile in children with multiple autoimmune diseases: the signature of HLA-DQ pleiotropic genes. Autoimmunity. 2012;45(6): $470-475$.

45. Lambert AP, Gillespie KM, Thomson G, et al. Absolute risk of childhood-onset type 1 diabetes defined by human leukocyte antigen class II genotype: a population-based study in the United Kingdom. J Clin Endocrinol Metab. 2004;89(8):4037-4043.

46. Kooy-Winkelaar Y, van Lummel M, Moustakas AK, et al. Glutenspecific T cells cross-react between HLA-DQ8 and the HLA-DQ2 $\alpha$ / DQ8 $\beta$ transdimer. J Immunol. 2011;187(10):5123-5129.

47. Lempainen J, Laine AP, Hammais A, et al. Non-HLA gene effects on the disease process of type 1 diabetes: from HLA susceptibility to overt disease. J Autoimmun. 2015;61:45-53.

48. Akar HH. Contribution of KIR genes on the genetic predisposition to celiac disease and coexisting celiac disease and type 1 diabetes mellitus. Rev Esp Enferm Dig. 2015;107(9):547-553.

49. Ostensson M, Monten C, Bacelis J, et al. A possible mechanism behind autoimmune disorders discovered by genome-wide linkage and association analysis in celiac disease. PLoS One. 2013;8(8):e70174.

50. Maiti AK, Kim-Howard X, Viswanathan P, et al. Confirmation of an association between rs6822844 at the I12-I121 region and multiple autoimmune diseases: evidence of a general susceptibility locus Arthritis Rheum. 2010;62(2):323-329.

51. Romanos J, Barisani D, Trynka G, Zhernakova A, Bardella MT, Wijmenga C. Six new coeliac disease loci replicated in an Italian population confirm association with coeliac disease. JMed Genet. 2009; 46(1):60-63.

52. Plaza-Izurieta L, Castellanos-Rubio A, Irastorza I, et al. Revisiting genome wide association studies (GWAS) in coeliac disease: replication study in Spanish population and expression analysis of candidate genes. J Med Genet. 2011;48(7):493-496.
53. Lorini R, Scaramuzza A, Vitali L, et al. Clinical aspects of coeliac disease in children with insulin-dependent diabetes mellitus. J Pediatr Endocrinol Metab. 1996;9(Suppl 1):101-111.

54. Ventura A, Neri E, Ughi C, Leopaldi A, Citta A, Not T. Gluten-dependent diabetes-related and thyroid-related autoantibodies in patients with celiac disease. J Pediatr. 2000;137(2):263-265.

55. Tarnok A, Marosvolgyi T, Szabo E, Gyorei E, Decsi T. Low n-3 longchain polyunsaturated fatty acids in newly diagnosed celiac disease in children with preexisting type 1 diabetes mellitus. J Pediatr Gastroenterol Nutr. 2015;60(2):255-258.

56. Greco D, Maggio F. Selective immunoglobulin a deficiency in type 1 diabetes mellitus: a prevalence study in Western Sicily (Italy). Diabetes Metab J. 2015;39(2):132-136.

57. Chow MA, Lebwohl B, Reilly NR, Green PH. Immunoglobulin A deficiency in celiac disease. J Clin Gastroenterol. 2012;46(10):850-854.

58. Nucci AM, Virtanen SM, Becker DJ. Infant feeding and timing of complementary foods in the development of type 1 diabetes. Curr Diab Rep. 2015;15(9):628.

59. Virtanen SM, Knip M. Nutritional risk predictors of beta cell autoimmunity and type 1 diabetes at a young age. Am JClin Nutr. 2003;78(6): 1053-1067.

60. Ziegler AG, Schmid S, Huber D, Hummel M, Bonifacio E. Early infant feeding and risk of developing type 1 diabetes-associated autoantibodies. JAMA. 2003;290(13):1721-1728.

61. Norris JM, Barriga K, Klingensmith G, et al. Timing of initial cereal exposure in infancy and risk of islet autoimmunity. JAMA. 2003;290(13):1713-1720.

62. Funda DP, Kaas A, Bock T, Tlaskalova-Hogenova H, Buschard K. Gluten-free diet prevents diabetes in NOD mice. Diabetes Metab Res Rev. 1999;15(5):323-327.

63. Funda DP, Kaas A, Tlaskalova-Hogenova H, Buschard K. Gluten-free but also gluten-enriched (gluten+) diet prevent diabetes in NOD mice; the gluten enigma in type 1 diabetes. Diabetes Metab Res Rev. 2008;24(1):59-63.

64. Larsen J, Dall M, Antvorskov JC, et al. Dietary gluten increases natural killer cell cytotoxicity and cytokine secretion. Eur J Immunol. 2014;44(10):3056-3067.

65. Dall M, Calloe K, Haupt-Jorgensen M, et al. Gliadin fragments and a specific gliadin 33-mer peptide close KATP channels and induce insulin secretion in INS-1E cells and rat islets of langerhans. PLoS One. 2013;8(6):e66474.

66. Gotfredsen CF, Buschard K, Frandsen EK. Reduction of diabetes incidence of BB Wistar rats by early prophylactic insulin treatment of diabetes-prone animals. Diabetologia. 1985;28(12):933-935.

67. Nadal I, Donat E, Ribes-Koninckx C, Calabuig M, Sanz Y. Imbalance in the composition of the duodenal microbiota of children with coeliac disease. J Med Microbiol. 2007;56(Pt 12):1669-1674.

68. Tlaskalova-Hogenova H, Stepankova R, Farre M, et al. Autoimmune reactions induCD by gliadin feeding in germ-free AVN rats and athymic nude mice. Animal models for celiac disease. Ann N Y Acad Sci. 1997;815:503-505.

69. Stepankova R, Tlaskalova-Hogenova H, Sinkora J, Jodl J, Fric P. Changes in jejunal mucosa after long-term feeding of germfree rats with gluten. Scand J Gastroenterol. 1996;31(6):551-557.

70. Helmerhorst EJ, Zamakhchari M, Schuppan D, Oppenheim FG. Discovery of a novel and rich source of gluten-degrading microbial enzymes in the oral cavity. PLoS One. 2010;5(10):e13264.

71. Moody MA, Santra S, Vandergrift NA, et al. Toll-like receptor $7 / 8$ (TLR7/8) and TLR9 agonists cooperate to enhance HIV-1 envelope antibody responses in rhesus macaques. J Virol. 2014;88(6):3329-3339.

72. Trynka G, Wijmenga C, van Heel DA. A genetic perspective on coeliac disease. Trends Mol Med. 2010;16(11):537-550.

73. Assmann TS, Brondani Lde A, Boucas AP, Canani LH, Crispim D. Toll-like receptor 3 (TLR3) and the development of type 1 diabetes mellitus. Arch Endocrinol Metab. 2015;59(1):4-12.

74. Kalliomaki M, Satokari R, Lahteenoja H, et al. Expression of microbiota, toll-like receptors, and their regulators in the small intestinal mucosa in celiac disease. J Pediatr Gastroenterol Nutr. 2012;54(6):727-732. 
Nutrition and Dietary Supplements

Dovepress

\section{Publish your work in this journal}

Nutrition and Dietary Supplements is an international, peer-reviewed, open access journal focusing on research into nutritional requirements in health and disease, impact on metabolism and the identification and optimal use of dietary strategies and supplements necessary for normal growth and development. The journal welcomes papers covering

original research, basic science, clinical \& epidemiological studies, reviews and evaluations, guidelines, expert opinion and commentary, case reports and extended reports. The manuscript management system is completely online and includes a very quick and fair peer-review system, which is all easy to use.

Submit your manuscript here: http://www.dovepress.com/nutrition-and-dietary-supplements-journal 